\title{
Remineralization and recycling of iron, thorium and organic carbon by heterotrophic marine protists in culture
}

\author{
K. Barbeau*, E. B. Kujawinski**, J. W. Moffett*** \\ Department of Marine Chemistry and Geochemistry, Woods Hole Oceanographic Institution, Woods Hole, \\ Massachusetts 02543, USA
}

\begin{abstract}
To characterize trace metal cycling in marine systems as mediated by heterotrophic protists, we conducted a series of laboratory experiments in 2-organism model systems consisting of bacteria and protistan grazers. Trace metal isotopes $\left({ }^{59} \mathrm{Fe}\right.$ and $\left.{ }^{234} \mathrm{Th}\right),{ }^{14} \mathrm{C}$, and bulk organic carbon measurements were used to follow the chemical transformation of bacterial carbon and associated trace metals by several different grazer species. Results indicate that grazers were able to cause repartitioning of Th and regeneration of Fe from bacterial prey into the dissolved phase $(<0.2 \mu \mathrm{m})$, even in particle-rich laboratory cultures. For both $\mathrm{Th}$ and $\mathrm{Fe}$, protist grazing led to the formation of relatively stable dissolved and colloidal metal-organic species. Metal/carbon ratios of the particle pool in some model systems with grazers were significantly altered, indicating a decoupling of trace metal and organic carbon cycling through the grazing process. Different protist species exhibited substantial variation (up to a factor of 10) in their ability to quantitatively remobilize trace metals from bacterial prey. The implications of these findings for trace metal cycling in marine systems are discussed.
\end{abstract}

KEY WORDS: Marine protists · Iron · Thorium · Organic carbon · Recycling

\section{INTRODUCTION}

Heterotrophic protists in the nanoplanktonic size class $(2-20 \mu \mathrm{m})$ are potentially an important influence on the marine geochemistry of trace metals. Small protist grazers are a primary sink for bacteria and similarly sized algal cells $(0.1-1 \mu \mathrm{m})$ in marine systems (Azam et al. 1983, Fenchel 1987), and such particles are known to constitute a major reservoir of particlereactive trace metals (Cho \& Azam 1990, Lee et al. 1993). Phagotrophic digestion of particles by protists is likely to be accompanied by lowered $\mathrm{pH}$ (Fok et al.

Present addresses:

${ }^{*}$ Department of Chemistry and Biochemistry, University of California, Santa Barbara, California 93106, USA

${ }^{* *}$ Department of Chemistry, The Ohio State University, Columbus, Ohio 43210, USA

${ }^{* * *}$ Corresponding author: E-mail: jmoffett@whoi.edu
1982), intense enzymatic activity (Fok et al. 1984), reactive oxygen species (Stossel 1974), and high concentrations of reduced organic material. This chemical environment can cause changes in the redox state and coordination chemistry of ingested trace metals, which can have significant impacts on the mobility and bioavailability of trace metal species.

A number of radiotracer studies have indicated that protistan grazers are capable of regenerating trace metals from ingested prey to the dissolved phase, and in some cases these regenerated trace metals have been shown to be available for biological uptake (Hutchins et al. 1993, Hutchins \& Bruland 1994, Twiss \& Campbell 1995, Barbeau et al. 1996, Twiss et al. 1996, Chase \& Price 1997). Ecological studies indicate that, in HNLC (high nitrate, low chlorophyll) regions, recycling of iron as mediated by microzooplankton grazers may be a key parameter in ecosystem productivity (Landry et al. 1997). Thus the available evidence 
suggests that the effect of protist grazing on trace metals in the oceans is both geochemically and ecologically significant.

This study presents some of the first data on the regeneration and recycling of cell-associated Fe and Th isotopes in conjunction with cellular organic carbon by heterotrophic protists in laboratory culture. Despite the widespread use of naturally occurring Th isotopes as analogues for particle-reactive species (Clegg \& Whitfield 1991, Gustafsson et al. 1997) and as tracers of particulate organic carbon (POC) export from the upper ocean (e.g. Buesseler et al. 1992, 1995, Murray et al. 1996), almost nothing is known about the actual mechanism of Th cycling via protists and associated organisms of the 'microbial loop'. Very few model system studies have examined the mechanism of Fe recycling in seawater via protistan grazing (Hutchins \& Bruland 1994, Chase \& Price 1997). Both of these studies employed the grazer Paraphysomonas sp. In the present study several different grazer species (including Paraphysomonas) were examined in terms of $\mathrm{Fe}$, Th and organic carbon remineralization.

In the first experiment, a model system study, the size fractionation of $\mathrm{Fe}$ and $\mathrm{Th}$ isotopes and organic carbon was followed as a heterotrophic nanoflagellate (Cafeteria sp., a free-living flagellate $3-5 \mu$ m diameter) consumed bacterial prey. Next a sequence of experiments was conducted in order to determine the relative abilities of 3 different kinds of protists to remobilize cell-associated Fe and Th (Cafeteria sp.; Uronema sp., a benthic scuticociliate $7-15 \mu \mathrm{m}$ in length; and Paraphysomonas imperforata, a free-living flagellate 5-7 $\mu \mathrm{m}$ in diameter, which sometimes attaches to surfaces). Finally, in order to make a more detailed comparison of Fe and organic carbon cycling by 2 different heterotrophic protists, simultaneous grazing experiments were carried out with nanoflagellates Cafeteria sp. and $P$. imperforata grazing on the same bacterial prey labeled with ${ }^{14} \mathrm{C}$ and ${ }^{59} \mathrm{Fe}$.

\section{METHODS}

Model system study - trace metal and organic carbon dynamics in cultures of the grazer Cafeteria sp. Radiolabeled and non-labeled heterotrophic bacteria (Halomonas halodurans, 0.5-1 $\mu \mathrm{m}$ in size) for this experiment were grown in $0.2 \mu \mathrm{m}$ filtered, autoclaved Vineyard Sound seawater (VSW) with $0.06 \%$ yeast extract added. Yeast-extract-enriched VSW was inoculated with bacteria from an agar slant monoculture, and radio-tracers $\left({ }^{59} \mathrm{Fe},{ }^{234} \mathrm{Th}\right)$ were added. Parallel non-labeled bacterial cultures were started at the same time. ${ }^{59} \mathrm{Fe}$ was obtained from New England Nuclear as $\mathrm{Fe}(\mathrm{III})$ salt in dilute $\mathrm{HCl}$, and added to the bacterial culture at a concentration of $30 \mu \mathrm{Ci} \mathrm{l}^{-1}$. ${ }^{234} \mathrm{Th}$ was extracted from $200 \mathrm{~g}$ of uranyl nitrate (Fluka), using a cation exchange resin extraction procedure (Sackett et al. 1958). Cultures were grown on a shaker at room temperature and harvested by centrifugation after $3 \mathrm{~d}$ (stationary phase). Cells were spun down and resuspended 3 times in fresh VSW, and bacterial concentrates were stored overnight at $4{ }^{\circ} \mathrm{C}$.

Bacterial concentrates were resuspended in VSW to

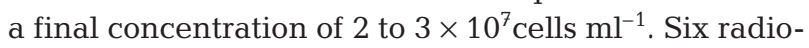
labeled and 6 non-labeled bacterial suspensions were set up in 2.51 polycarbonate bottles. Half of the labeled and non-labeled bacterial suspensions were inoculated from an exponential phase culture of the heterotrophic bicosoecid nanoflagellate Cafeteria sp. growing on rinsed, resuspended Halomonas halodurans (Cafeteria sp. clone Cflag isolated from a seawater aquarium, maintained on $H$. halodurans as prey). Protists were added to achieve an initial concentration of $10^{4}$ cells $\mathrm{ml}^{-1}$. Uninoculated bacterial suspensions (controls) and Cafeteria sp.-inoculated suspensions (experimental systems) were incubated without shaking at 20 to $22^{\circ} \mathrm{C}$ under normal laboratory light for $48 \mathrm{~h}$. Starting at $t_{0}$ with the inoculation of the grazer, bottles were sampled aseptically every $12 \mathrm{~h}$. Cultures were gently mixed by swirling or tipping the bottles prior to sampling.

Size fractionation of radiotracers was performed by non-sequential filtration, using Nuclepore polycarbonate filters of $0.2,1$, and $5 \mu \mathrm{m}$ pore size. Filtration was performed under low vacuum $(<100 \mathrm{~mm} \mathrm{Hg})$, and filters were not rinsed. At each time point, an unfiltered aliquot was taken as a total to which all particulate fractions were normalized, thereby correcting for tracer wall loss (generally $<10 \%$ ). Filters and totals were counted for gamma activity on a Canberra lowenergy germanium detector coupled to an Ortec multichannel analyzer, to a statistical counting error of $5 \%$ or less.

Additional $0.2 \mu \mathrm{m}$-filtered samples were taken at $t_{0}$ $t_{24}$, and $t_{48}$ using a reverse-flow filtration technique driven by head pressure (Nagata \& Kirchman 1990). This more gentle method of filtration was used as a measure of the degree to which direct filtration may have resulted in protist cell lysis. Reverse-flow filtrates were reserved for radio-isotope counting. Activity in filtrates was normalized to an equal volume of whole culture.

A $10 \mathrm{ml}$ aliquot of reverse-flow $0.2 \mu \mathrm{m}$ filtrate was used for ultrafiltration at $t_{48}$. Ultrafiltration was performed using centrifugal concentrators with a nominal molecular weight cut-off of 10000 MW (Macroseps with Omega-type membrane, made by Filtron Technology Corporation, Northborough, MA, USA). Both filtrate and retentate were reserved for radio-isotope counting. 
Samples for POC were taken from the non-labeled experimental and control bottles and vacuum filtered through Nuclepore polycarbonate filters (47 mm diameter, $0.2,1$, and $5 \mu \mathrm{m}$ pore size) in acid-cleaned glass vacuum filter holders. Filters and filter holders were pre-rinsed with reagent alcohol followed by Milli-Q water prior to filtering samples. After filtration, the filter was transferred to a $47 \mathrm{~mm}$ petri dish and immediately covered with $1 \mathrm{ml}$ of reagent alcohol.

Carefully keeping the filters wet with alcohol at all times, particulates were scraped off the filter surface using a Teflon-lined spatula. Particulates and reagent alcohol were quantitatively pipetted from the petri dish and transferred to a small Eppendorf tube. The filter was rinsed with $400 \mu \mathrm{l}$ reagent alcohol $(2 \times 200 \mu \mathrm{l}$ aliquots), also transferred to the Eppendorf tube. This procedure was adapted from the protocol of Cowen (1991) for individual particle analysis by electron microscopy. Mass balances with this method averaged $7.3 \pm 13 \%$ ( $n=5$; range: -5.1 to $22.4 \%$ ). Visual inspection of the filters also showed that no cells remained after scraping and transfer. The standard deviations on replicate samples using this method averaged $15.8 \pm$ $8.8 \%(\mathrm{n}=16$; range: 5 to $36 \%$; median $=12 \%)$. Samples with high inherent heterogeneity (e.g. significant aggregation in early protist cultures and bacterial controls) exhibited high sample $\sigma$ 's. Samples were stored under refrigeration until $\mathrm{CHN}$ analysis. Prior to $\mathrm{CHN}$ analysis, particulates in reagent alcohol were transferred to a pre-weighed Sn boat. Alcohol was completely evaporated on a hot plate set to low. POC samples were then analyzed on a Fisons Instruments EA 1108 Elemental Analyzer.

For dissolved organic carbon (DOC) samples, nonlabeled cultures were filtered by overpressure $\left(\mathrm{N}_{2}\right.$ gas, 2 to $3 \mathrm{psi}$ ) through a $0.2 \mu \mathrm{m}$ pore size, $47 \mathrm{~mm}$ diameter Anopore membrane filter (Whatman) in an in-line Teflon filter holder. Filtrate $(40 \mathrm{ml}$ ) was collected in a pre-combusted glass vial, acidified with 150 to $200 \mu \mathrm{l}$ of $50 \%$ (v/v) $\mathrm{H}_{3} \mathrm{PO}_{4}$, capped, and refrigerated until analysis. Total organic carbon (TOC) samples $(15 \mathrm{ml}$ whole culture aliquot + $15 \mathrm{ml}$ Milli-Q water) were similarly placed in glass vials, acidified, and stored under refrigeration. DOC and TOC samples were analyzed using a high-temperature combustion/discrete injection (HTC/DI) analyzer (Peltzer \& Brewer 1993), linked to a Li-Cor non-dispersive infra-red (NDIR) $\mathrm{CO}_{2}$ analyzer.

$\mathrm{pH}$ in experimental and control bottles was determined using an Orion Model 410A pH meter. Samples for cell counting by microscopy were taken from nonlabeled control and experimental cultures at each time point, and from the protistan inoculum culture at $t_{0}$. Samples for microscopy were preserved in $1 \%$ glutaraldehyde and refrigerated for 1 to $2 \mathrm{wk}$ until slides were made for microscopy using the acridine orange
(AO) staining procedure (Hobbie et al. 1977) and Nuclepore filters. (Sample storage was shown not to significantly reduce bacterial counts in our culture experiments. This protocol should not be followed for natural seawater samples.) Samples were counted on a Zeiss standard microscope equipped for epifluorescence microscopy with a BP 450 to 490 exciter filter, an FT510 chromatic beam splitter, and an LP520 barrier filter.

Species survey - trace metal remobilization efficiency. As a quick survey, each of the 3 experiments described in this section had only 1 experimental bottle with grazers, and 1 bacterial control. The interspecies comparison experiment (described in the next section) was performed later with replicates in order to substantiate the results of the species survey experiments for Cafeteria sp. and Paraphysomonas sp.

All protists were maintained on Halomonas halodurans as prey: Cafeteria sp., Uronema sp. (clone BBcil, a small scuticociliate isolated from Buzzard's Bay, MA, USA) and Paraphysomonas imperforata (clone VS1, a chrysomonad nanoflagellate isolated from Vineyard Sound). H. halodurans suspensions radiolabeled with ${ }^{234} \mathrm{Th}$ and ${ }^{59} \mathrm{Fe}$ were set up using the protocols outlined previously, and inoculated with exponential phase cultures of each grazer. Control and experimental bottles were incubated as described previously. Once the grazers had consumed 80 to $90 \%$ of the bacterial population (as determined by visual inspection, i.e. 'clearing' the suspension; this took approximately $24 \mathrm{~h}$ for Uronema sp. and $48 \mathrm{~h}$ for $P$. imperforata and Cafeteria sp.), the dissolved/solid partitioning of the radiotracers in experimental cultures versus bacteria controls was determined by vacuum filtration through $0.2 \mu \mathrm{m}$ Nuclepore membranes, as described previously.

Interspecies comparison - iron and organic carbon dynamics in grazing cultures of Cafeteria sp. versus Paraphysomonas imperforata. For this experiment, Halomonas halodurans labeled with ${ }^{59} \mathrm{Fe}$ and ${ }^{14} \mathrm{C}$ were grown in VSW supplemented with pyruvate, $\mathrm{NH}_{4}$, $\mathrm{PO}_{4}, \mathrm{f} / 2$ vitamins (Guillard \& Ryther 1962) and trace metals (Fe, Mn, Zn, and Co). Separate parallel cultures were grown for ${ }^{59} \mathrm{Fe}$ - and ${ }^{14} \mathrm{C}$-labeled bacteria. ${ }^{59} \mathrm{Fe}$ was added to the media as $\mathrm{FeCl}_{3}$ in dilute $\mathrm{HCl}(30 \mu \mathrm{Ci}$ $\mathrm{l}^{-1}$ ), and ${ }^{14} \mathrm{C}$ was added as sodium pyruvate $\left[2-{ }^{14} \mathrm{C}\right]-$ $\left(50 \mu \mathrm{Ci}^{-1}\right)$. Both isotopes were obtained from $\mathrm{New}$ England Nuclear. Protocols for growing bacteria, harvesting/rinsing, and setting up experimental bottles and bacteria controls were otherwise similar to those described previously. Grazing cultures of Cafeteria sp. and Paraphysomonas imperforata and bacteria controls were set up as 1 set of replicates with ${ }^{14} \mathrm{C}$-labeled bacteria (i.e. 2 bacteria controls, 2 Cafeteria sp. grazing cultures, and $2 P$. imperforata grazing cultures), and 1 set of replicates with ${ }^{59} \mathrm{Fe}$-labeled bacteria. Parallel non-labeled incubations were set up to monitor cell 
numbers, stable organic carbon, and pH as described previously. Bacteria concentrations at the start of the experiment were $1 \times 10^{7}$ cells ml ${ }^{-1}$. Cafeteria sp. and $P$. imperforata were added to an initial concentration of 5 and $8 \times 10^{3}$ cells $\mathrm{ml}^{-1}$, respectively.

Experimental bottles and bacteria controls were incubated as in previous experiments, and sampled every $12 \mathrm{~h}$ from $t_{0}$ (immediately after adding protistan inocula) to $t_{48}$. Size-fractionated samples $(0.2,1$, and $5 \mu \mathrm{m}$ ) for ${ }^{14} \mathrm{C}$ and ${ }^{59} \mathrm{Fe}$ were taken by vacuum filtration as described previously for radioisotope samples. Additional 0.2 and $0.05 \mu \mathrm{m}{ }^{14} \mathrm{C}$ and ${ }^{59} \mathrm{Fe}$ filtrate samples were taken from the grazing cultures at $t_{48}$ using syringe filtration with Nuclepore membranes in SwinLok filter holders.

Ultrafiltration of ${ }^{14} \mathrm{C}$ and ${ }^{59} \mathrm{Fe}$ was performed in this experiment by a dialysis technique. Sterile cellulose ester dispodialyzers (Spectrum, 10000 and 1000 molecular weight cut-off [MWCO], $5 \mathrm{ml}$ capacity) were filled with VSW and added to each grazing culture at $t_{24}$. The dispodialyzers were allowed to remain suspended in the grazing cultures until $t_{48}$, during which time dissolved ${ }^{14} \mathrm{C}$ and ${ }^{59} \mathrm{Fe}(<10000$ or $<1000 \mathrm{MWCO}) \mathrm{col}-$ lected inside the bags by passive diffusion. For collection, the dispo-dialyzers were removed and their contents placed in sample cups for radioisotope counting.

Samples for ${ }^{59} \mathrm{Fe}$ were counted as previously described on a Canberra low-energy germanium detector. ${ }^{14} \mathrm{C}$ samples were counted on a Beckman Scintillation Counter. ${ }^{14} \mathrm{C}$ filtrate and total samples in liquid scintillation vials were acidified and allowed to de-gas for $2 \mathrm{~h}$ under a fume hood to remove $\mathrm{CO}_{2}$ before adding ScintiVerseII scintillation cocktail (Fisher Scientific) and capping vials.

\section{RESULTS}

In all of these experiments, grazing cultures were compared to live bacteria-only controls in order to determine the specific effects of grazer activity on the cycling of trace metals and organic carbon. While this basic experimental design has been used with great success to study the influence of grazers on nutrient cycling (e.g. Caron et al. 1988), it is important to recognize that bacteria-only controls cannot fully account for potential feedback loops that may occur in grazing cultures, e.g. the effects of grazing on prey growth rate and nutrient uptake. Additional experiments to address this issue could be conducted with dead bacteria controls. Live bacteria controls could also be incubated in dialysis bags suspended in active grazing cultures in order to permit diffusive exchange of substances released by the grazers. Such experiments were beyond the scope of the current work.

\section{Model system study}

While the bacteria cell concentrations in the controls remained relatively constant in the first model system experiment, the grazers in the experimental grazing bottles reduced the bacterial cells $\mathrm{ml}^{-1}$ by about an order of magnitude (Fig. 1). In the grazing cultures during the latter part of the experiment ( $t_{36}$ to $t_{48}$ ), there was an additional amount of bacterial biomass contained in clumps and filaments of cells. $\mathrm{pH}$ over the time course of the experiment changed from 8.3 to 8.0 in the bacteria controls, and 8.2 to 7.8 in the grazing cultures.

Fig. 2 shows the size class dynamics in the bacteria controls and grazing cultures for organic carbon (Fig. 2A,B), ${ }^{234}$ Th (Fig. 2C,D) and ${ }^{59} \mathrm{Fe}$ (Fig. 2E,F). The dissolved size class was defined by a $0.2 \mu \mathrm{m}$ cut-off. The $0.2-1 \mu \mathrm{m}$ size class contained bacteria cells. The 1-5 $\mu \mathrm{m}$ size class contained bacterial aggregates in the bacteria-only controls, and contained protist cells and bacterial aggregates in the grazing cultures. The $>5 \mu \mathrm{m}$ size class included larger bacterial aggregates, filaments, and a few associated protists (confirmed by microscopic examination of AO-stained 1 and $5 \mu \mathrm{m}$ Nuclepore filters).

DOC levels in the control decreased over the course of the experiment, presumably due to bacterial uptake. By $t_{48}$ DOC levels approached 1 to $1.5 \mathrm{mg} \mathrm{l}^{-1}$. DOC uptake was accompanied by an increase in POC in the bacterial size class, and a slight decrease in TOC from 7.4 to $7.1 \mathrm{mg} \mathrm{l}^{-1}$. In the grazing cultures, there was a removal of POC from the bacterial size class. DOC levels remained relatively constant. TOC decreased from $8.5 \mathrm{mg} \mathrm{l}^{-1}$ at the start of the experiment to $5.3 \mathrm{mg} \mathrm{l}^{-1}$ by

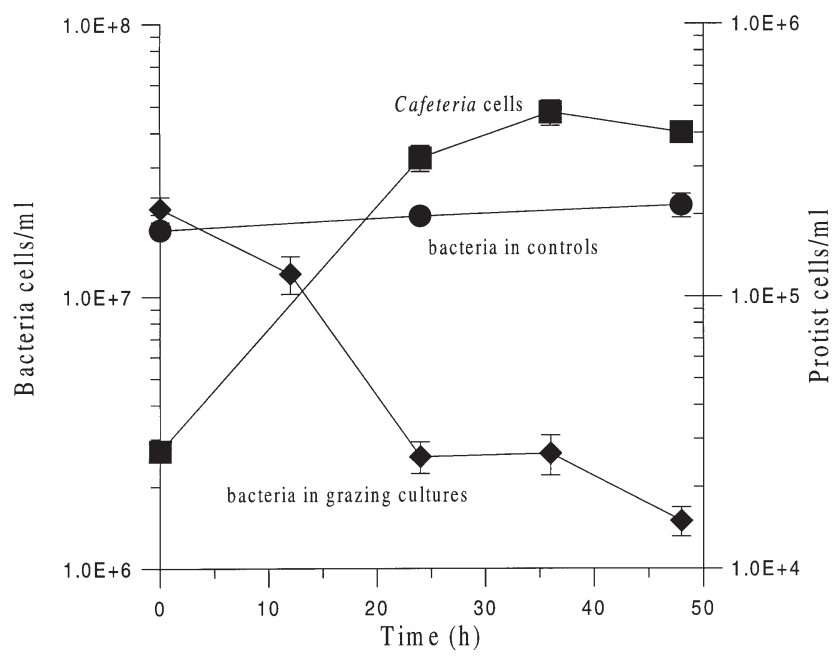

Fig. 1. Population dynamics. Bacteria and protozoan cell numbers versus time in grazing cultures and bacteria controls. Error bars shown are the standard deviation of triplicate cultures 

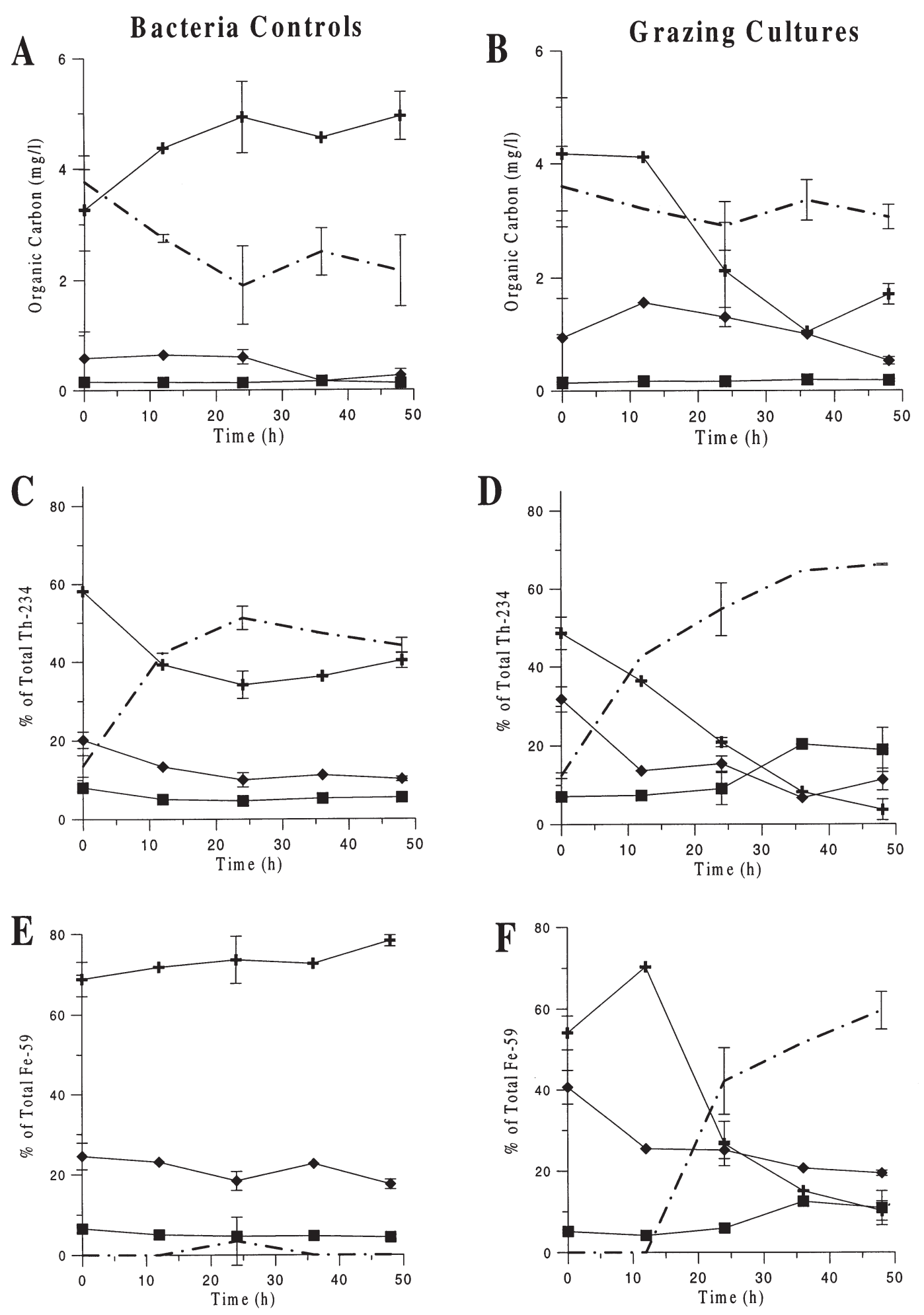

Fig. 2. Size fractionation of $(\mathrm{A}, \mathrm{B})$ organic carbon, $(\mathrm{C}, \mathrm{D}){ }^{234} \mathrm{Th}$, and $(\mathrm{E}, \mathrm{F}){ }^{59} \mathrm{Fe}$ in bacteria controls and grazing cultures. Dashed line $=<0.2 \mu \mathrm{m}_{i} \boldsymbol{+}=0.2-1 \mu \mathrm{m}_{i}=1-5 \mu \mathrm{m}_{;} \mathbf{\square}=>5 \mu \mathrm{m}$. Error bars shown are the standard deviation of triplicate cultures. $t_{12}$ and $t_{36}$ for all size fractions $>0.2 \mu \mathrm{m}$ are single culture measurements with no error 
$t_{48}$, reflecting the combined respiratory activity of the grazers and bacteria.

${ }^{234} \mathrm{Th}$ in the bacteria control (Fig. 2C) exhibited significant desorption from the bacteria cells over the first $12 \mathrm{~h}$, with relative equilibration thereafter at about $40 \%$ dissolved ${ }^{234} \mathrm{Th}$. Th was associated primarily with the external surfaces of the bacteria cells ( 80 to $85 \%$ of bacterial ${ }^{234} \mathrm{Th}$ was removable by rinsing with Ti(III) EDTA-citrate solution; Hudson \& Morel 1989). These results suggested that Th was in reversible equilibrium between the cell surface and dissolved phase. In the grazing system (Fig. 2D) ${ }^{234} \mathrm{Th}$ reached about $70 \%$ partitioning into the dissolved phase by $t_{48} \cdot{ }^{59} \mathrm{Fe}$ in the bacteria controls (Fig. 2E) remained entirely associated with the bacterial size class (single cells in the $0.2-1 \mu \mathrm{m}$ fraction, and cell aggregates in the 1-5 $\mu \mathrm{m}$ fraction) throughout the experiment. Only about $5 \%$ of the bacterial ${ }^{59} \mathrm{Fe}$ was able to be removed with the Ti(III) EDTA-citrate reagent, indicating that it was primarily intracellular. In the grazing system (Fig. 2F), ${ }^{59} \mathrm{Fe}$ was effectively removed from the $0.2-1 \mu \mathrm{m}$ size class and remobilized into the dissolved phase.

We will henceforth refer to grazer-mediated changes in Th distribution as repartitioning, since Th is bound reversibly to the bacterial prey. We will refer to $\mathrm{Fe}$ remobilization as regeneration, since Fe was present within the cell at the start of the experiment, like a nutrient or micronutrient.

It is apparent that the vacuum filtration and reverseflow filtration results for ${ }^{59} \mathrm{Fe}$ and ${ }^{234} \mathrm{Th}$ agree fairly well within experimental error (Table 1). This suggests that potential artifacts in the vacuum filtration data due to cell lysis were not significant. Ultrafiltration results indicate that a substantial fraction of the ${ }^{59} \mathrm{Fe}$ and ${ }^{234} \mathrm{Th}$ in the $<0.2 \mu \mathrm{m}$ size class passed through a 10000 MWCO (46\% for ${ }^{59} \mathrm{Fe}$, and $73 \%$ for $\left.{ }^{234} \mathrm{Th}\right)$.

The variation in the ${ }^{234} \mathrm{Th} / \mathrm{C}$ ratio in the total particle pool (i.e. $>0.2 \mu \mathrm{m}$ ) is shown over the course of the ex-

Table 1. Vacuum filtration, reverse-flow filtration, and ultrafiltration results in experimental (grazing) cultures for Cafeteria sp. model system study at $t_{48}$. Values shown are the average and standard deviation of measurements made in triplicate cultures. MWCO: molecular weight cut-off

\begin{tabular}{|c|c|c|c|c|c|}
\hline & $\begin{array}{l}\%<0.2 \mu \mathrm{m} \\
\text { vacuum } \\
\text { filtration }^{\mathrm{a}}\end{array}$ & $\begin{array}{l}\%<0.2 \mu \mathrm{m} \\
\text { reverse-flow } \\
\text { filtration }^{\mathrm{b}}\end{array}$ & $\%$ retentate ${ }^{\mathrm{c}}$ & $\begin{array}{l}\text { Ultrafiltration } \\
\% \text { filtrate }\end{array}$ & \% recovery \\
\hline${ }^{59} \mathrm{Fe}$ & $59.5 \pm 4.6$ & $53.3 \pm 0.9$ & $21.9 \pm 2.2$ & $45.8 \pm 2.1$ & $67.7 \pm 4.3$ \\
\hline${ }^{234} \mathrm{Th}$ & $66.1 \pm 0.2$ & $69.5 \pm 3.3$ & $22.2 \pm 0.6$ & $72.9 \pm 4.1$ & $95.1 \pm 4.7$ \\
\hline \multicolumn{6}{|c|}{$\begin{array}{l}\text { a \% of total activity passing through } 0.2 \mu \mathrm{m} \text { pore size, using vacuum filtration } \\
\text { b \% of total activity passing through } 0.2 \mu \mathrm{m} \text { pore size, using reverse-flow filtration } \\
\text { c } \text { Retentate is }>10000 \mathrm{MWCO},<0.2 \mu \mathrm{m} \\
\text { d Filtrate is }<10000 \mathrm{MWCO}\end{array}$} \\
\hline
\end{tabular}

periment in the bacteria controls and in the Cafeteria sp. grazing cultures (Fig. 3A). There was a drop in the $\mathrm{Th} / \mathrm{C}$ ratio in both controls and grazing cultures over the first $12 \mathrm{~h}$, most likely due to a combination of DOC uptake and Th desorption. Thereafter the controls maintained equilibrium, while there was an increase in the $\mathrm{Th} / \mathrm{C}$ ratio of particles in the grazing culture. In the grazing culture, the increase in the $\mathrm{Th} / \mathrm{C}$ ratio of particles was driven by the increase in the $\mathrm{Th} / \mathrm{C}$ ratio of the largest particles in the system (>5 $\mu \mathrm{m})$ (Fig. 3B).

\section{Species survey}

The results of the species survey (Table 2) are presented in terms of the excess $\%{ }^{234} \mathrm{Th}$ and ${ }^{59} \mathrm{Fe}$ solubilized in grazing cultures relative to the controls - the percentage of dissolved ${ }^{59} \mathrm{Fe}$ and ${ }^{234} \mathrm{Th}$ in the bacterial controls has been subtracted from the percentage of dissolved ${ }^{59} \mathrm{Fe}$ and ${ }^{234} \mathrm{Th}$ in the grazing cultures. Cafeteria sp. appeared to be the most effective organism at solubilizing $\mathrm{Fe}$ and $\mathrm{Th}$, remobilizing 68 and $42 \%$ (respectively) of the 2 trace metals relative to the controls. Paraphysomonas imperforata was substantially less effective than Cafeteria sp. at remobilizing Fe and Th, achieving increases of only 25 and $2 \%$ (respectively) relative to controls. For Uronema sp., Fe and Th remobilization was intermediate between the percentages observed for the 2 flagellates.

\section{Interspecies comparison}

Stable DOC levels at $t_{0}$ in all systems were about $4 \mathrm{mg} \mathrm{l}^{-1}$ organic carbon, similar to the Cafeteria sp. model system experiment described previously (see Fig. 2A,B). In the bacteria control (Fig. $4 \mathrm{~A}),{ }^{14} \mathrm{C}$ remained primarily associated with the $0.2-1 \mu \mathrm{m}$ size class, with some in bacterial aggregates $(1-5 \mu \mathrm{m})$. The bacteria population in the controls dropped slightly from $1 \times 10^{7}$ to $9 \times 10^{6}$ cells ml $^{-1}$ over the course of the experiment, with a slight $\mathrm{pH}$ drop from 7.8 to 7.7 . In the Cafeteria sp. grazing cultures (Fig. 4B), there was removal of ${ }^{14} \mathrm{C}$ from the $0.2-1 \mu \mathrm{m}$ size class, accompanied by a significant increase in dissolved ${ }^{14} \mathrm{C}$. Most of the bacterial ${ }^{14} \mathrm{C}$ was apparently respired by the grazer. The bacteria population in the Cafeteria sp. culture was reduced to $2.5 \times 10^{6}$ cells $\mathrm{ml}^{-1}$, and the protists achieved a final density of $5 \times 10^{6}$ cells $\mathrm{ml}^{-1}$. Protist growth was accompanied by a $\mathrm{pH}$ 
drop from 7.8 at $t_{0}$ to 7.3 at $t_{48}$. In the Paraphysomonas imperforata grazing cultures (Fig. $4 \mathrm{C}$ ),${ }^{14} \mathrm{C}$ was removed from the $0.2-1 \mu \mathrm{m}$ size class and primarily respired, with a small increase in dissolved ${ }^{14} \mathrm{C}$. The bacteria population in the $P$. imperforata cultures was reduced to $1.1 \times 10^{6}$ cells $\mathrm{ml}^{-1}$, and the protists achieved a final density of $5 \times 10^{6}$ cells ml ${ }^{-1}$. Protist growth was accompanied by a $\mathrm{pH}$ drop from 7.8 at $t_{0}$ to 7.3 at $t_{48}$.

In the bacteria controls, ${ }^{59} \mathrm{Fe}$ remained almost entirely associated with bacteria cells (Fig. 4D), although Ti(III) EDTA-citrate washes indicated that up to $60 \%$ of the bacterial iron was extracellular (as defined by lability to the Ti(III) EDTA-citrate rinse). In the Cafeteria sp. grazing cultures ${ }^{59} \mathrm{Fe}$ was removed from the $0.2-1 \mu \mathrm{m}$ size class and transferred into the dissolved phase $(<0.2 \mu \mathrm{m})$ (Fig. 4E). In the Paraphysomonas imperforata cultures, ${ }^{59} \mathrm{Fe}$ was also removed from the $0.2-1 \mu \mathrm{m}$ size class, and increased both in the dissolved phase and in the 1-5 $\mu \mathrm{m}$ size class (Fig. 4F). As in the species survey experiments, P. imperforata proved to be less effective than Cafeteria sp. at regenerating $\mathrm{Fe}$ to the dissolved phase from bacteria prey ( $34 \%$ regenerated to the dissolved phase for $P$. imperforata vs $63 \%$ for Cafeteria sp.).

While both Cafeteria sp.and Paraphysomonas imperforata produced a significant fraction of colloidal organic carbon and $\mathrm{Fe}$ in the $<0.2 \mu \mathrm{m}$ size class (Fig. 4B, $\mathrm{C}, \mathrm{E}, \mathrm{F}$ ), in the Cafeteria sp. cultures more of this material was able to pass through the various smaller size cut-offs $(0.05 \mu \mathrm{m}, 10$ and $1 \mathrm{~K} \mathrm{MWCO})$ (Fig. 5). This was particularly the case for Fe.

$\mathrm{Fe} / \mathrm{C}$ ratios of the total particle pool $(>0.2 \mu \mathrm{m})$ varied substantially over the time course of the experiment in the grazing cultures (Fig. 6). It is apparent that while the $\mathrm{Fe} / \mathrm{C}$ ratio of particles in the Cafeteria sp. cultures remained essentially constant within error, there was a significant increase in the $\mathrm{Fe} / \mathrm{C}$ ratio of particles in the Paraphysomonas imperforata cultures. Fe/C ratios in the bacteria controls remained essentially constant over the course of the experiment (data not shown).

\section{DISCUSSION}

In the first model system study (Fig. 2) it is apparent that the redistribution of $\mathrm{Th}$ and $\mathrm{Fe}$ as a consequence of grazing is quite similar-both were effectively transferred into the dissolved phase in the grazing culture, with some additional transferrance into the $>5 \mu \mathrm{m}$ size class. In addition, in the species survey experiments (Table 2), the extent of Th repartitioning by each species paralleled the extent of Fe regeneration. For Fe, incorporated primarily intracellularly by the bacterial prey, the effect of grazing is similar to
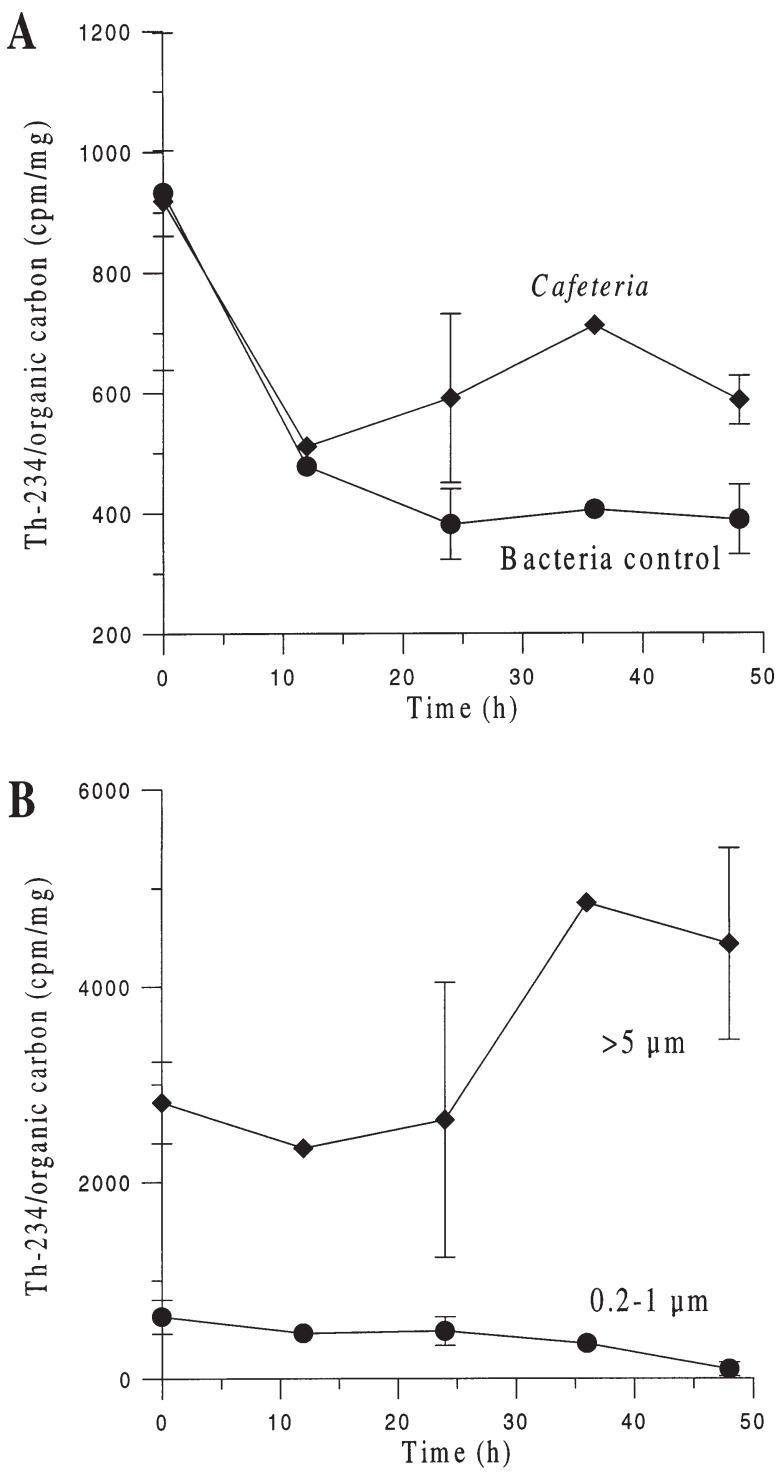

Fig. 3. (A) Variation in ${ }^{234} \mathrm{Th} / \mathrm{C}$ ratio in total particle pool in the Cafeteria sp. culture and bacteria control. (B) Variation in ${ }^{234} \mathrm{Th} / \mathrm{C}$ ratio in Cafeteria sp. culture in largest $(>5 \mu \mathrm{m})$ and smallest $(0.2-1 \mu \mathrm{m})$ particle size classes. Error bars shown are the standard deviation of triplicate cultures. $t_{12}$ and $t_{36}$ are single culture measurements with no error. cpm: counts per minute

Table 2. Excess $\%{ }^{234} \mathrm{Th}$ and ${ }^{59} \mathrm{Fe}$ remobilized to the dissolved phase $(<0.2 \mu \mathrm{m})$ in grazing cultures relative to controls in interspecies survey experiments

\begin{tabular}{|lcc|}
\hline \multirow{2}{*}{ Species } & \multicolumn{3}{c|}{ Excess \% remobilized } \\
& ${ }^{234} \mathrm{Th}$ & ${ }^{59} \mathrm{Fe}$ \\
\hline Uronema sp. & 20 & 53 \\
Paraphysomonas imperforata & 2 & 25 \\
Cafeteria sp. & 42 & 68 \\
\hline
\end{tabular}



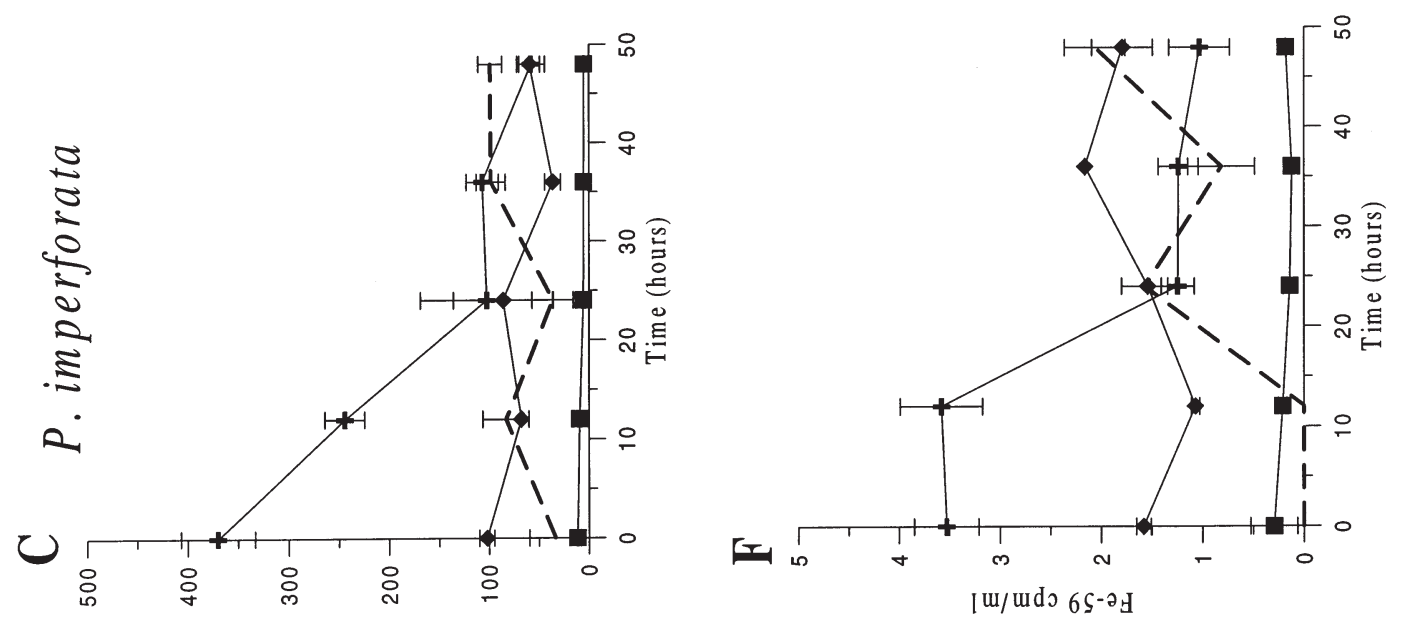

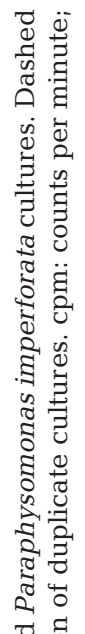

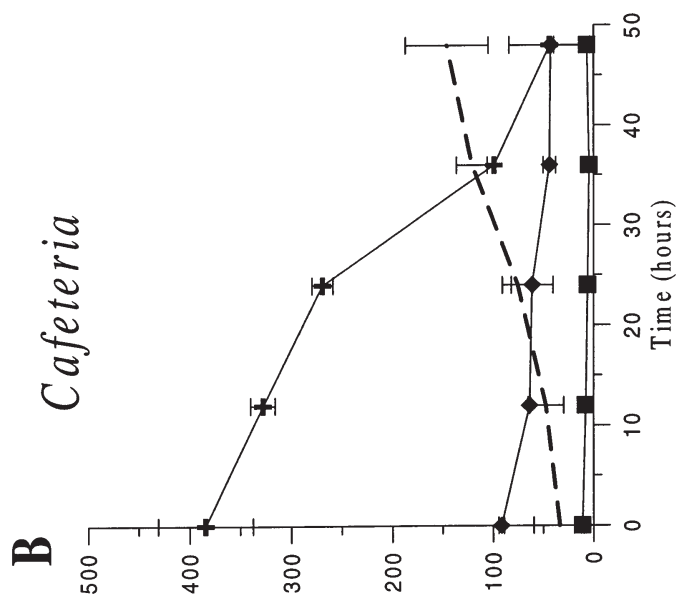

[ w/udp $\downarrow$ I-J

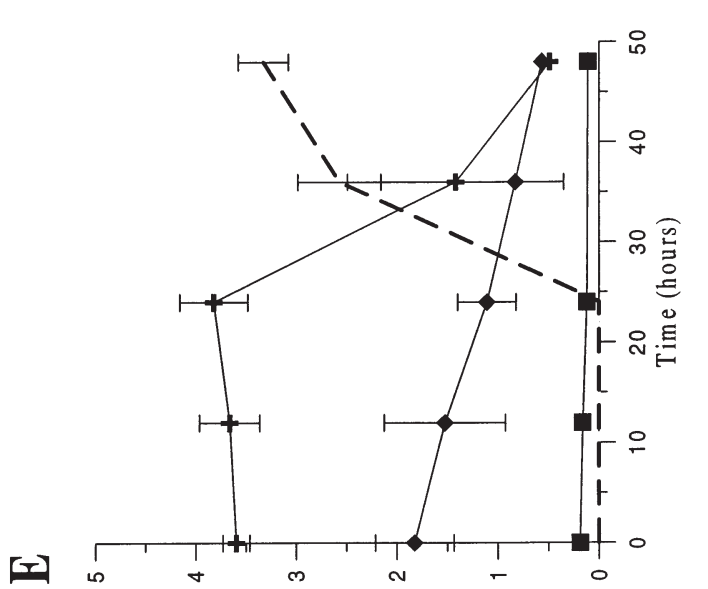

로유.?

क

늘

क⿺辶

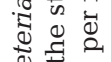

过

के है

苟 否

ชี

矛苛

[ แ/ यdo $6 \mathrm{~S}^{-2}$
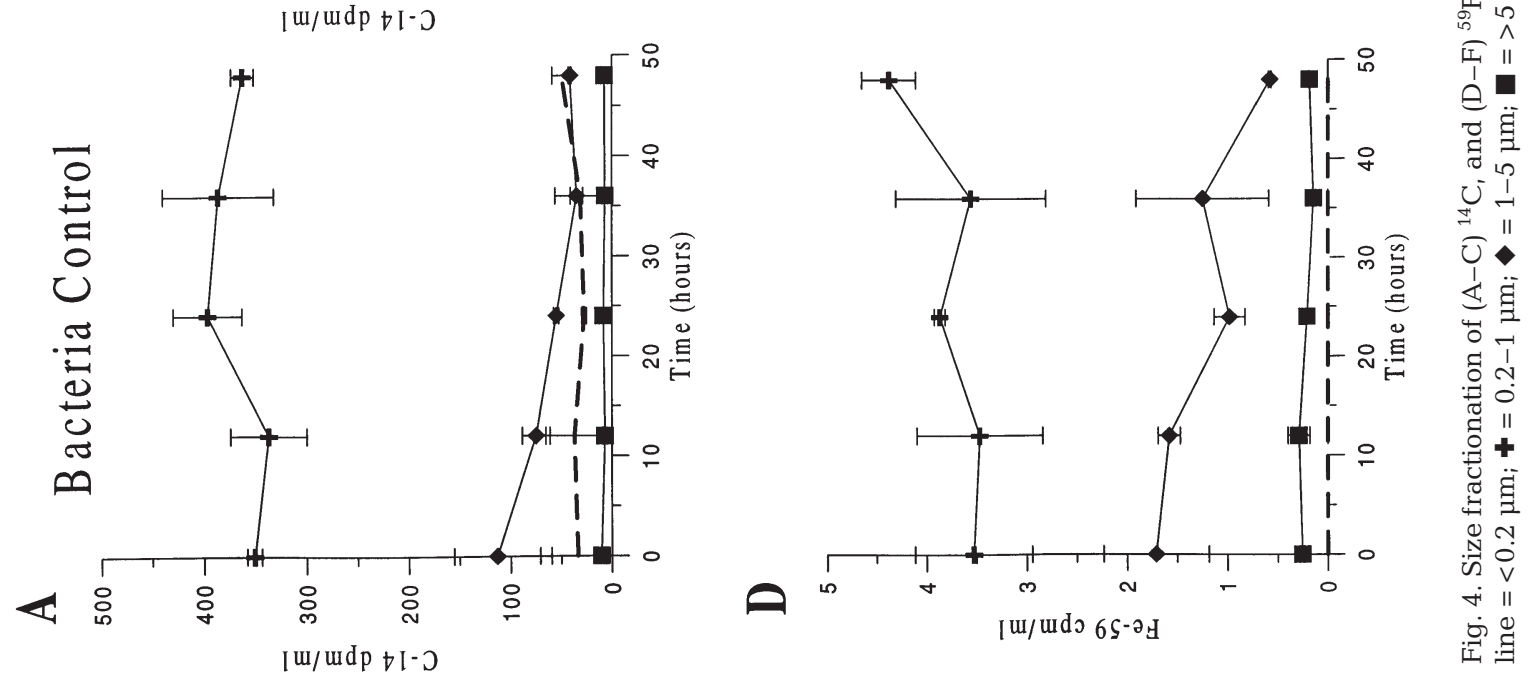

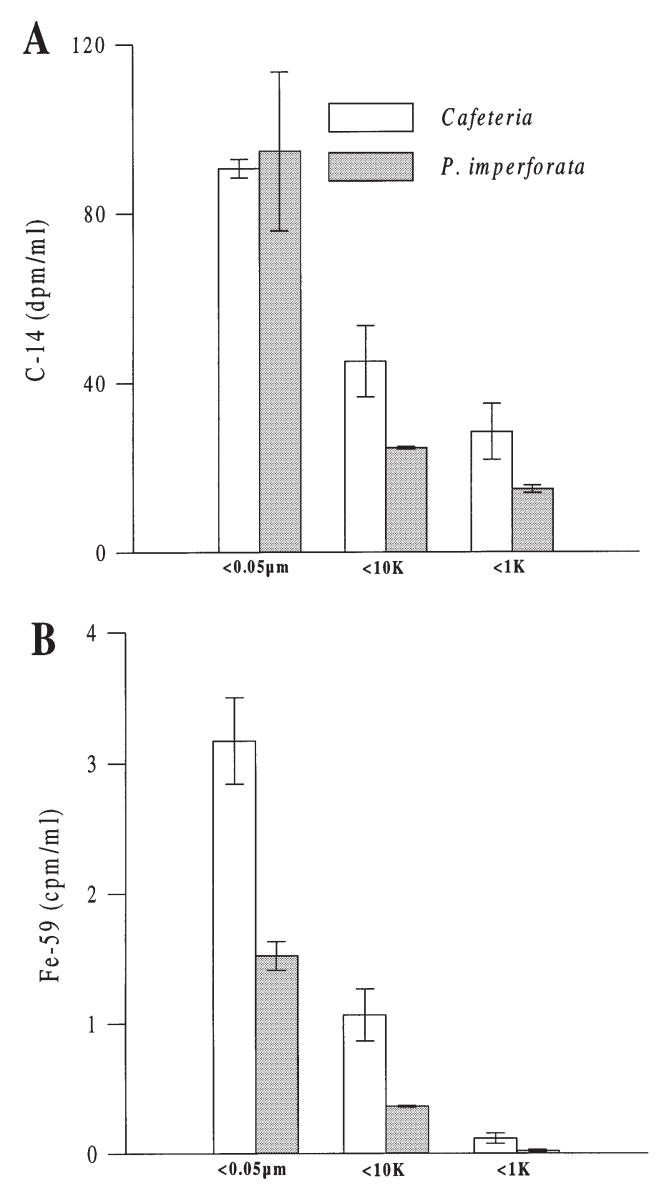

Fig. 5. Colloidal size fractionation of (A) ${ }^{14} \mathrm{C}$ and (B) ${ }^{59} \mathrm{Fe}$ in Cafeteria sp. and Paraphysomonas imperforata cultures at $t_{48}$. Error bars are the standard deviation of duplicate cultures

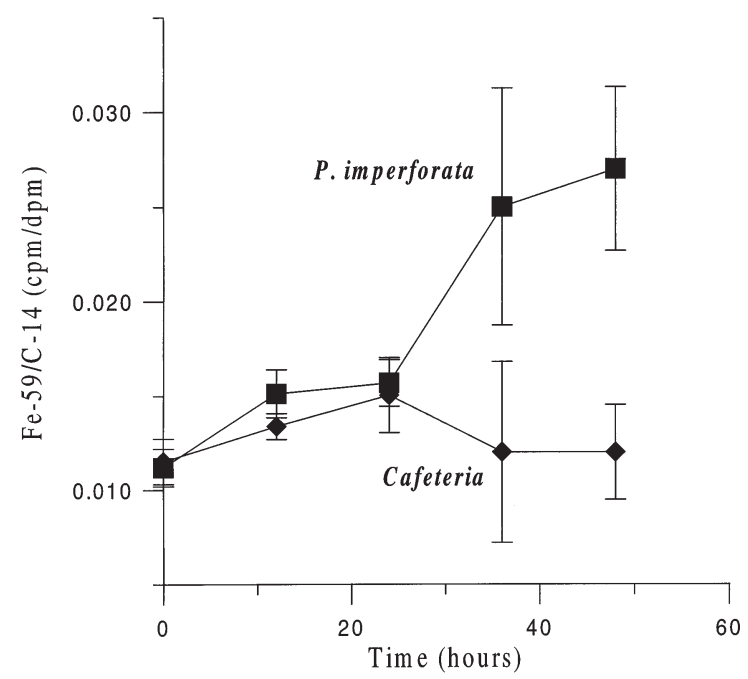

Fig. 6. Variation over time in ${ }^{59} \mathrm{Fe} /{ }^{14} \mathrm{C}$ ratio in total particle pool $(>0.2 \mu \mathrm{m})$ in Cafeteria sp. and Paraphysomonas imperforata cultures. Error bars are the standard deviation of duplicate cultures nutrient remineralization (Caron et al. 1988). For Th, bound reversibly to the surface of bacterial cells, the most important effect of grazing is most likely its changing of the chemistry and size spectrum of the organic matter in the system. The similarities between Fe and Th behavior suggest that changing the particle size spectrum and chemistry is the dominant net effect of grazing, and this process may be important for other hydrolyzed particle reactive metals, like aluminum.

In studies of metazoan grazers (Reinfelder \& Fisher 1991, Hutchins et al. 1995), strong correlations have been found between grazer assimilation efficiency and prey subcellular partitioning of trace elements. In this study the assimilation efficiencies of protists for Fe and Th were not measured. There should, however, be a correlation between grazer assimilation of an element and its eventual fate. The similar redistribution of Fe and Th among particulate and dissolved size classes as a result of protist grazing indicates that different subcellular partitioning of $\mathrm{Fe}$ and Th in the prey did not result in their fractionation during grazer processing. In addition, Fe behaved similarly in the first model system experiment with Cafeteria sp. (Fig. 2F) and the interspecies comparison experiment with Cafeteria sp. (Fig. 4E), despite the fact that in the former case Fe was almost entirely intracellular in the prey, and about $60 \%$ extracellular in the latter.

In intracellular (phagotrophic) digestion, the initial pH can drop as low as 2 (Fok et al. 1982), and during subsequent steps hydrolytic enzymes operative at $\mathrm{pH} 5$ attack bacterial membrane components (Fok et al. 1984). Such processes might solubilize Th, associated non-specifically with external membranes. Copepods utilize a combination of mechanical disruption and extracellular digestive enzymes at circumneutral gut $\mathrm{pH}$ to absorb soluble (i.e. cytoplasmic) nutrients from prey (Vonk 1960). Differences in the chemistry of intracellular versus extracellular digestion likely account for the larger fractionation between membrane-bound and cytoplasmic trace metals observed in studies of copepods as compared to this study.

The experiments conducted in this work were not designed to cause iron limitation of the protist grazers. Under such conditions, if $\mathrm{Fe}$ as a necessary nutrient was in short supply, one might expect some differences in the cycling of Fe and Th by grazers. This is supported by the work of Chase \& Price (1997) on Fe limitation of protists.

In the Cafeteria sp. grazing culture in the first model system study, the size class distribution of both ${ }^{59} \mathrm{Fe}$ and ${ }^{234} \mathrm{Th}$ by the end of the experiment was dominated by the $<0.2 \mu \mathrm{m}$ (dissolved) size class (Fig. 2). The stability of particle-reactive $\mathrm{Fe}$ and $\mathrm{Th}$ in the dissolved phase is contrary to expectation for these culture systems, where high particle concentrations should pro- 
vide abundant surface area for adsorption. One explanation for this seeming paradox is that both $\mathrm{Fe}$ and Th were stabilized in the $<0.2 \mu \mathrm{m}$ size class due to complexation by truly dissolved and colloidal organic ligands produced via grazing. Ultrafiltration results (Table 1, Fig. 5) indicate that both colloidal and dissolved species of Th and Fe were produced as a result of grazing. Production of colloidal organic particles as a consequence of grazing was observed here (Fig. 5A), and has been documented in other laboratory studies of heterotrophic protists (Nagata \& Kirchman 1992, Tranvik 1994, Pelegri et al. 1999). Regeneration of Zn and $\mathrm{Cd}$ as organic complexes by protist grazers has been indirectly observed in other studies (Twiss \& Campbell 1995).

For Th, organic complexation is rarely considered as an influence on dissolved/solid partitioning. If adsorption of Th to bacterial surfaces (Lee et al. 1993) and subsequent ingestion by protistan grazers can result in repartitioning of Th to the dissolved phase in the form of low and high molecular weight organic complexes, this could reduce the overall scavenging of Th by particles. Coale \& Bruland (1987) postulated that ${ }^{234} \mathrm{Th}$ could be stabilized in the oceanic surface stratified euphotic zone as a result of rapid particle cycling by the microbial loop. A recent compilation of JGOFS ${ }^{234} \mathrm{Th}$ data from the central equatorial Pacific (Dunne et al. 1997) suggests that protist-mediated repartitioning of ${ }^{234} \mathrm{Th}$ is a key parameter in the upper ocean cycling of this important tracer. Our work presents the first measurements in laboratory culture of Th repartitioning by microzooplankton, and suggests that the speciation of grazer-repartitioned Th may be an important factor in determining particle scavenging rates.

$\mathrm{Fe}$, thought to be a limiting nutrient in some areas of the oceans, has been shown to be almost entirely complexed in the dissolved phase by organic ligands (Gledhill \& Van den Berg 1994, Rue \& Bruland 1995, Wu \& Luther 1995). Secretion of siderophores (strong Fe(III)-binding compounds) by marine bacteria has been postulated as a potential source of iron binding ligands in seawater (e.g. Butler 1998). Our data suggest that protistan grazing may be an additional source of iron binding ligands in seawater, through the regeneration of iron from bacterial biomass. Similar theories have been suggested for metazoan grazing (Hutchins \& Bruland 1994) and viral lysis of cells (Gobler et al. 1997). The binding strength and bioavailability of the putative iron ligands produced in our model systems is unknown. Given the postulated importance of protistmediated remineralization of $\mathrm{Fe}$ in HNLC regions (Landry et al. 1997), these are important considerations for further study.

Our data suggest that microzooplankton grazers can decouple the particle cycling of Th and Fe from that of bulk organic matter, resulting in increases in the Th/C and $\mathrm{Fe} / \mathrm{C}$ ratios of particles, particularly those in the larger size class (Fig. 3B). The Fe/C ratio of particles in Paraphysomonas imperforata grazing cultures differed substantially from that in Cafeteria sp. cultures (Fig. 6). Several processes could be responsible for the effects observed. Preferential remineralization of organic carbon by grazers and bioaccumulation of trace metals would tend to increase metal/carbon ratios. Increases in the surface reactivity of the particle pool due to grazing could also drive metal/carbon ratios up. Physical processes of aggregation can also affect metal/carbon ratios by moving small particles and colloids with their associated metals up the particle size spectrum.

Previous studies have suggested the importance of biological processes in affecting the spatial and temporal variation of the $\mathrm{POC} /{ }^{234} \mathrm{Th}$ ratio of marine particles (e.g. Moran et al. 1993, Buesseler et al. 1995). A recent modeling study, however, suggests that physical adsorption-aggregation can explain observed variations in $\mathrm{POC} /{ }^{234} \mathrm{Th}$ with particle size (Burd et al. 1999). The work presented here, demonstrating significant changes in the $\mathrm{Th} / \mathrm{C}$ and $\mathrm{Fe} / \mathrm{C}$ ratios of particles (as well as the dissolved/solid distribution of Th and $\mathrm{Fe}$ ) as a direct result of protist grazing, suggests that biological processes do need to be considered for a complete understanding of metal scavenging in marine systems.

Heterotrophic protists in the marine environment are a diverse group (Lee \& Capriulo 1990). The species survey experiments (Table 2) indicated substantial variation in the degree to which different protists could repartition Th and regenerate Fe from cells to the dissolved phase. Differences between the 2 nanoflagellates, Cafeteria sp. and Paraphysomonas imperforata, were particularly extreme, despite the similar morphology of those 2 organisms. Results of the interspecies comparison between Cafeteria sp. and $P$. imperforata again indicated (Fig. 4) that Cafeteria sp. was substantially more effective than P. imperforata at regenerating $\mathrm{Fe}$ to the dissolved phase. These differences extended to the submicron size class, in that $P$. imperforata appeared to generate more colloidal (rather than truly dissolved) species of ${ }^{14} \mathrm{C}$ and ${ }^{59} \mathrm{Fe}$ (Fig. 5).

Interspecies differences in the regeneration of nutrients (specifically phosphorus) by heterotrophic flagellates have been observed previously (Eccleston-Parry \& Leadbeater 1995). Differences in P regeneration in that study were ascribed to differences in life cycle strategies and/or internal C/P ratios between fast- and slow-growing species. In the present study, Cafeteria sp. and Paraphysomonas imperforata demonstrated very similar growth kinetics and grazing thresholds, as demonstrated by the dynamics of bacterial ${ }^{14} \mathrm{C}$ in the 2 
grazing cultures (Fig. 4B,C), and reported bacterial and protist cell densities (see 'Results'). Thus differences in growth rates and grazing rates do not seem to have been a factor. Assimilation efficiencies were not measured in the present study, but increased assimilation of iron by $P$. imperforata relative to Cafeteria sp. may have contributed to differences in iron remobilization efficiency between the 2 organisms.

In related work, we have observed that Cafeteria sp. has a greater capacity than Paraphysomonas imperforata to remobilize $\mathrm{Fe}$ from inorganic Fe hydroxides (Barbeau \& Moffett 1998). It seems likely that the observed interspecies differences in trace metal remobilization capacity (for both inorganic and bacterial trace metal substrates) are related to specific characteristics of the grazers' digestive metabolism, such as vacuole $\mathrm{pH}$ and/or residence time. There are also significant qualitative and quantitative differences in the characteristics of organic matter produced by the 3 protist species studied here, as noted in a companion study to this work (Kujawinski 2000) that may contribute to the interspecies differences seen here. Another factor may be the frequency of re-ingestion of waste particles by different grazers (Strom et al. 1998, Pelegri et al. 1999).

The high concentrations of bacteria and protists used in our model systems represent a significant deviation from most natural systems. Although in previous work we have successfully extrapolated rate measurements of processes measured in grazing cultures to the natural environment (Barbeau \& Moffett 1998, 2000), caution should be exercised in the interpretation of culture experiments as representative of oceanic systems. Due to the higher concentrations of protists and prey cells in our model systems, the rate and magnitude of the processes therein are elevated relative to what they would be in more dilute natural systems. The basic mechanisms, however, should remain the same.

It is possible that, in the water column of the open ocean, with protists grazing on single bacteria cells in suspension, regeneration/repartitioning of trace metals to the dissolved phase by grazers would be more efficient than what we observed in our model systems, due to the much lower particle concentrations in the oceanic water column. However, consumption of particle-reactive trace metals associated with prey cells by protist grazers could still result in the formation of colloidal and organically complexed forms of these trace metals, as observed in laboratory culture. Because this changes trace metal bioavailability and/ or particle reactivity, these processes will have an important impact on trace metal cycling. Future experiments that more closely replicate open-ocean conditions in terms of bacterial abundance and protist species would be desirable.
Protists occur in a variety of aquatic environments, most of which are more concentrated than the oceanic water column. Even within the open ocean, particlerich microenvironments like marine snow have been shown to be important in the cycling of materials and energy in oceanic systems (Knauer et al. 1982, Honjo et al. 1984, Pilskaln \& Honjo 1987, Alldredge et al. 1993). Protistan grazers are known to be an important component of such microenvironments (Caron et al. 1986, Alldredge \& Silver 1988). It is likely that in such microenvironments, protist-mediated effects on trace metal speciation and transport would be similar to what we have observed in our model systems. The same is true for other environments that are relatively high in particle and protist abundance-coastal systems and air-sea and sediment-water interfaces.

\section{CONCLUSIONS}

The present study has contributed to our growing understanding of how protistan grazers mediate the biogeochemical cycling of particle-reactive trace metals in marine systems. Principle results can be summarized as follows:

- Protists appear to be able to mobilize trace metals bound extracellularly and those contained intracellularly to a similar extent.

- In some cases, protist remobilization of trace metals from prey can stabilize otherwise particle-reactive trace metals like Th and Fe in the dissolved phase, apparently through the formation of dissolved and colloidal metal-organic complexes.

- Protist grazing can decouple the cycling of trace metals and organic carbon, resulting in changes in the metal/carbon ratio of the particle pool in grazing systems.

- Significant interspecies differences exist in the extent to which grazers can remobilize cell-associated trace metals.

Acknowledgements. We thank Alan Fleer for help with the ${ }^{234} \mathrm{Th}$ isolation protocol. The culture collection of Dave Caron (University of Southern California) provided all the bacteria and protists used in this study, and we thank him for his assistance and advice on all aspects of this work. This work was financially supported by a Department of Defense ONRNDSEG Graduate Fellowship, Office of Naval Research AASERT Award (N00014-94-1-0711), and the National Science Foundation EGB Program (OCE-9523910). Contribution No. 10415 from the Woods Hole Oceanographic Institution.

\section{LITERATURE CITED}

Alldredge AL, Silver MW (1988) Characteristics, dynamics and significance of marine snow. Prog Oceanogr 20:41-82 
Alldredge AL, Passow U, Logan BE (1993) The abundance and significance of a class of large, transparent organic particles in the ocean. Deep-Sea Res 40:1131-1140

Azam F, Fenchel T, Field JG, Meyer-Reil LA, Thingstad F (1983) The ecological role of water-column microbes in the sea. Mar Ecol Prog Ser 10:257-263

Barbeau KA, Moffett JW (1998) Dissolution of iron oxides by phagotrophic protists: using a novel method to quantify reaction rates. Environ Sci Technol 32:2969-2975

Barbeau K, Moffett JW (2000) Laboratory and field studies of colloidal iron oxide dissolution as mediated by phagotrophy and photolysis. Limnol Oceanogr 45:827-835

Barbeau K, Moffett JW, Caron D, Croot PL, Erdner D (1996) Role of protozoan grazing in relieving iron limitation of phytoplankton. Nature 380:61-64

Buesseler KO, Bacon MP, Cochran JK, Livingston HD (1992) Carbon and nitrogen export during the JGOFS North Atlantic Bloom Experiment estimated from ${ }^{234} \mathrm{Th}:{ }^{238} \mathrm{U}$ disequilibria. Deep-Sea Res 39:1115-1137

Buesseler KO, Andrews JA, Hartman MC, Belastock R, Chai F (1995) Regional estimates of the export flux of particulate organic carbon derived from thorium-234 during the JGOFS EqPac program. Deep-Sea Res 42:777-804

Burd A, Moran SB, Jackson GA (1999) A coupled adsorptionaggregation model of the $\mathrm{POC} /{ }^{234} \mathrm{Th}$ ratio of marine particles. Deep-Sea Res I 47:103-120

Butler A (1998) Acquisition and utilization of transition metal ions by marine organisms. Science 281:207-210

Caron DA, Davis PG, Madin LP, Sieburth JMcN (1986) Enrichment of microbial populations in macroaggregates (marine snow) from surface waters of the North Atlantic. J Mar Res 44:543-565

Caron DA, Goldman JC, Dennett MR (1988) Experimental demonstration of the roles of bacteria and bacterivorous protozoa in plankton nutrient cycles. Hydrobiologia 159: $27-40$

Chase Z, Price NM (1997) Metabolic consequences of iron deficiency in heterotrophic marine protozoa. Limnol Oceanogr 42:1673-1684

Cho BC, Azam F (1990) Major role of bacteria in biogeochemical fluxes in the ocean's interior. Nature 332:441-443

Clegg SL, Whitfield M (1991) A generalized model for the scavenging of trace metals in the open ocean. II. Thorium scavenging. Deep-Sea Res 38:91-120

Coale KH, Bruland KW (1987) Oceanic stratified euphotic zone as elucidated by ${ }^{234} \mathrm{Th}:{ }^{238} \mathrm{U}$ disequilibria. Limnol Oceanogr 32:189-200

Cowen JP (1991) Individual particle analysis. In: Hurd DC, Spencer DW (eds) Marine particles: analysis and characterization. Geophysical monograph, Vol 63. American Goephysical Union, Washington, DC, p 429-436

Dunne JP, Murray JW, Young J, Balistrieri LS, Bishop J (1997) ${ }^{234} \mathrm{Th}$ and particle cycling in the central equatorial Pacific. Deep-Sea Res II 44:2049-2083

Eccleston-Parry JD, Leadbeater BSC (1995) Regeneration of phosphorus and nitrogen by four species of heterotrophic nanoflagellates feeding on three nutritional states of a single bacterial strain. Appl Environ Microbiol 61:1033-1038

Fenchel T (1987) Ecology of protozoa: the biology of freeliving phagotrophic protists. Science Tech Publishers, Madison

Fok AK, Lee Y, Allen RD (1982) The correlation of digestive vacuole $\mathrm{pH}$ and size with the digestive cycle in Parmecium caudatum. J Protozool 29:409-414

Fok AK, Muraoka JH, Allen RD (1984) Acid phosphatase in the digestive vacuoles and lysosomes of Paramecium caudatum: a timed study. J Protozool 31:216-220
Gledhill M, Van den Burg CMG (1994) Determination of complexation of iron (III) with natural organic complexing ligands in seawater using cathodic stripping voltammetry. Mar Chem 47:41-54

Gobler CJ, Hutchins DA, Fisher NS, Cosper EM, Sanudo-Wilhelmy SA (1997) Release and bioavailability of C, N, P, Se, and Fe following viral lysis of a marine chrysophyte. Limnol Oceanogr 42:1492-1504

Guillard RRL, Ryther JH (1962) Studies of marine planktonic diatoms. I. Cyclotella nana Hustedt and Detonula confervacea Cleve. Can J Microbiol 8:229-239

Gustafsson O, Gschwend PM, Buesseler KO (1997) Using ${ }^{234} \mathrm{Th}$ disequilibria to estimate the vertical removal rates of polycyclic aromatic hydrocarbons from the surface ocean. Mar Chem 57:11-23

Hobbie JE, Daley R, Jasper S (1977) Use of Nuclepore filters for counting bacteria by fluorescence microscopy. Appl Environ Microbiol 33:1225-1228

Honjo S, Doherty DW, Agarwal YC, Asper V (1984) Direct optical assessment of large amorphous aggregates (marine snow) in the deep ocean. Deep-Sea Res 31:67-76

Hudson RJM, Morel FMM (1989) Distinguishing between extra- and intracellular iron in marine phytoplankton. Limnol Oceanogr 34:1113-1120

Hutchins DA, Bruland KW (1994) Grazer-mediated regeneration and assimilation of $\mathrm{Fe}, \mathrm{Zn}$ and $\mathrm{Mn}$ from planktonic prey. Mar Ecol Prog Ser 110:259-269

Hutchins DA, DiTullio GR, Bruland KW (1993) Iron and regenerated production: evidence for biological iron recycling in two marine environments. Limnol Oceanogr 38: $1242-1255$

Hutchins DA, Wang W, Fisher NS (1995) Copepod grazing and the biogeochemical fate of diatom iron. Limnol Oceanogr 40:989-994

Knauer GH, Hebel D, Cipriano F (1982) Marine snow: major site of primary production in coastal waters. Nature 300 : $630-631$

Kujawinski EB (2000) The effect of protozoan grazers on the cycling of polychlorinated biphenyls (PCBs) in marine systems. PhD thesis, MIT/WHOI Joint Program, Woods Hole Oceanographic Institution, Woods Hole, MA

Landry MR and 12 others (1997) Iron and grazing constraints on primary production in the central equatorial Pacific: an EqPac synthesis. Limnol Oceanogr 42:405-418

Lee JJ, Capriulo GM (1990) The ecology of marine protozoa: an overview. In: Capriulo GM (ed) Ecology of marine protozoa. Oxford University Press, New York, p 3-39

Lee T, Barg E, Lal D, Azam F (1993) Bacterial scavenging of ${ }^{234} \mathrm{Th}$ in surface ocean waters. Mar Ecol Prog Ser 96: 109-116

Moran SB, Buesseler KO, Niven SEH, Bacon MP, Cochran JK, Livingston HD, Michaels AF (1993) Regional variability in size fractionated $\mathrm{C} /{ }^{234} \mathrm{Th}$ ratios in the upper ocean: importance of biological recycling. The 3rd Scientific Meeting of the Oceanography Society, Seattle, WA, April 13-16; published program, p 152

Murray JW and 6 others (1996) Export flux of particulate organic carbon from the central equatorial Pacific determined using a combined drifting trap $-{ }^{234} \mathrm{Th}$ approach. Deep-Sea Res 43:1095-1132

Nagata T, Kirchman DL (1990) Filtration-induced release of dissolved free amino acids: application to cultures of marine protozoa. Mar Ecol Prog Ser 68:1-5

Nagata T, Kirchman DL (1992) Release of macromolecular organic complexes by heterotrophic marine flagellates. Mar Ecol Prog Ser 83:233-240

Pelegri SP, Christaki U, Dolan J, Rassoulzadegan F (1999) 
Particulate and dissolved organic carbon production by the heterotrophic nanoflagellate Pteridomonas danica Patterson and Fenchel. Microb Ecol 37:276-284

Peltzer ET, Brewer PG (1993) Some practical aspects of measuring DOC - sampling artifacts and analytical problems with marine samples. Mar Chem 41:243-252

Pilskaln CH, Honjo S (1987) The fecal pellet fraction of biogeochemical particle fluxes to the deep sea. Global Biogeochem Cycles 1:31-48

Reinfelder JR, Fisher NS (1991) The assimilation of elements ingested by marine copepods. Science 251:794-796

Rue EL, Bruland KW (1995) Complexation of iron(III) by natural organic ligands in the Central North Pacific as determined by a new competitive ligand equilibration/adsorptive cathodic stripping voltammetric method. Mar Chem 50:117-138

Sackett WM, Potratz HA, Goldberg ED (1958) Thorium content of ocean water. Science 128:204-205

Stossel TP (1974) Phagocytosis (first of 3 parts). N Engl J Med 290:717-723

Editorial responsibility: Fereidoun Rassoulzadegan, Villefranche-sur-Mer, France
Strom SL, Morello TA, Bright KJ (1998) Protozoan size influences algal pigment degradation during grazing. Mar Ecol Prog Ser 164:189-197

Tranvik L (1994) Colloidal and dissolved organic matter excreted by a mixotrophic flagellate during bacterivory and autotrophy. Appl Environ Microbiol 60:1884-1888

Twiss MR, Campbell PGC (1995) Regeneration of trace metals from picoplankton by nanoflagellate grazing. Limnol Oceanogr 40:1418-1429

Twiss MR, Campbell PGC, Auclair JC (1996) Regeneration, recycling and trophic transfer of trace metals by microbial food-web organisms in the pelagic surface waters of Lake Erie. Limnol Oceanogr 41:1425-1437

Vonk HJ (1960) Digestion and metabolism. In: Waterman TH (ed) The physiology of Crustacea. Academic Press, New York, p 291-313

Wu J, Luther GW (1995) Complexation of Fe(III) by natural organic ligands in the Northwest Atlantic Ocean by a competitive ligand equilibration method and kinetic approach. Mar Chem 50:159-177

Submitted: January 27, 2000; Accepted: December 19, 2000 Proofs received from author(s): March 6, 2001 